\title{
Asian Woolly Hackberry Aphid, Shivaphis celti Das (Insecta: Hemiptera: Aphididae) ${ }^{1}$
}

Susan E. Halbert and Paul M. Choate ${ }^{2}$

\section{Introduction}

An Asian woolly hackberry aphid, Shivaphis celti Das, was found for the first time in Florida in Jacksonville, Duval County, on sugarberry (Celtis laevigata Willd.) on 13 August 1997 by Florida Department of Agriculture \& Consumer Services' Division of Plant Industry Plant Inspector Flewellyn W. Podris. Since then, these Asian woolly hackberry aphids have been collected in counties spanning most of Florida. Shivaphis celti was found in Georgia about a year before its discovery in Florida.

There are several species of Asian woolly hackberry aphids. The East and Central Asian genus Shivaphis contains six described species, of which four are in Shivaphis sensu stricto, and the other two are in the subgenus Shivaphis (Sinishivaphis) (Quednau and Remaudière 1985; Remaudière and Remaudière 1997; Zhang and Zhong 1982). They are found primarily on Celtis spp., with one described species, Shivaphis (Sinishivaphis) tilisucta Zhang, from China on Tilia (Zhang and Zhong 1990). Two more species, included in Shivaphis in older literature, are now in the genus Neocranaphis (Remaudière and Remaudière 1997). These species infest bamboo and closely related plants. No Asian woolly hackberry aphids other than $S$. celti are known to occur in the Western Hemisphere.

\section{Description}

Shivaphis celti is conspicuous because the aphids secrete copious quantities of bluish white wax. The aphids are small, about 2 to $2.5 \mathrm{~mm}$ long. As is often the case with Myzocallidini, the anal plate is deeply cleft. The cauda is finger-like rather than constricted into a knob. There are conspicuous wax glands on the abdomen. Siphunculi are pore-like, on a slightly raised cone. Wings veins are bordered, particularly at the distal ends. Antennal joints are darkened, giving the antenna a striped appearance. The processus terminalis is rather short, about three times as long as wide. These characters will separate $S$. celti from other genera of aphids on Celtis, and from other Asian woolly hackberry aphids (Blackman and Eastop 1994; Quednau and Remaudière 1985).

1. This document is EENY-288, originally published as DPI Entomology Circular 392, one of a series of Featured Creatures from the Entomology and Nematology Department, Florida Cooperative Extension Service, Institute of Food and Agricultural Sciences, University of Florida. Published: June 2003. This document is also available on Featured Creatures Website at http://creatures.ifas.ufl.edu. Please visit the EDIS Website at http://edis.ifas.ufl.edu. Additional information on these organisms, including many color photographs, is available at the Entomology and Nematology Department website at http://entnemdept.ifas.ufl.edu/.

2. Susan E. Halbert, Division of Plant Industry, Florida Department of Agriculture and Consumer Services and Paul M. Choate, Entomology and Nematology Department, Institute of Food and Agricultural Sciences, University of Florida, Gainesville, FL.

The Institute of Food and Agricultural Sciences (IFAS) is an Equal Employment Opportunity - Affirmative Action Employer authorized to provide research, educational information and other services only to individuals and institutions that function without regard to race, creed, color, religion, age, disability, sex, sexual orientation, marital status, national origin, political opinions or affiliations. For information on obtaining other extension publications, contact your county Cooperative Extension Service office. Florida Cooperative Extension Service / Institute of Food and Agricultural Sciences / University of Florida / Larry R. Arrington, Interim Dean 


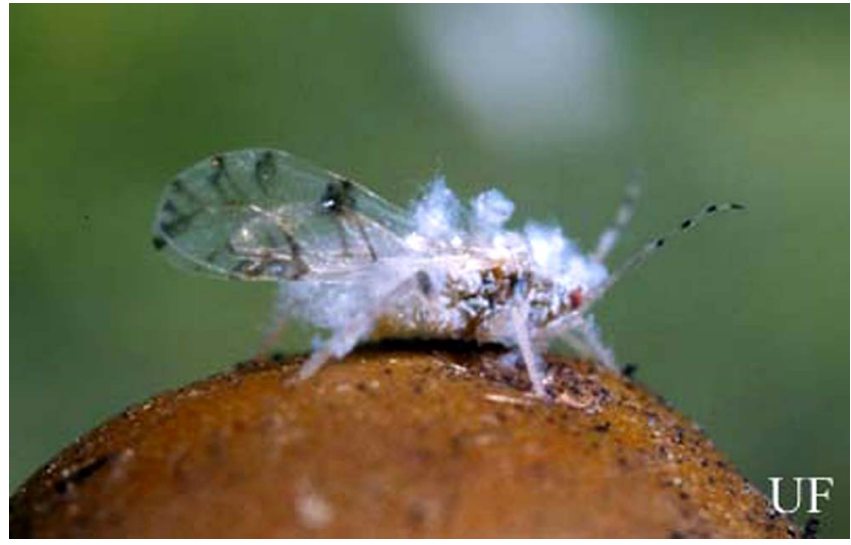

Figure 1. Winged adult female Shivaphis celti Das, an Asian hackberry aphid, on hackberry. Credits: P.M. Choate, University of Florida

\section{Life History}

Summer adults are all female and parthenogenetic. Summer adults may be winged or wingless. In the autumn (October in Gainesville), winged males and wingless oviparae can be found. These mate to produce an overwintering egg that allows the aphids to survive the winter when there are no leaves on the trees. Raychaudhuri et al. (1981) described the oviparous forms.

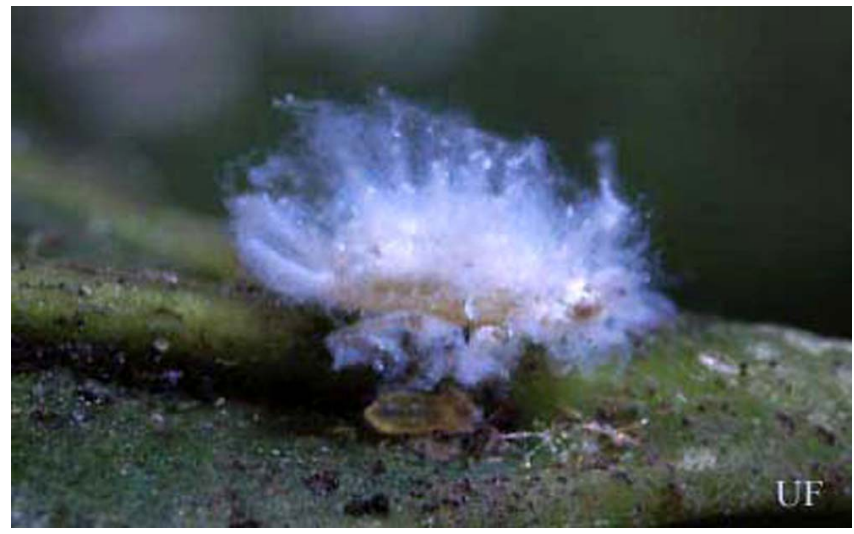

Figure 2. Wingless adult Shivaphis celti Das, an Asian hackberry aphid, on hackberry. Credits: P.M. Choate, University of Florida

\section{Hosts}

Shivaphis celti probably is restricted to Celtis, although Chakrabarti (1988) found $S$. celti occasionally on Arundo donax L. Host species of Celtis include: C. australis L., lote-tree, Mediterranean hackberry (Chakrabarti 1988; Raychaudhuri et al. 1980); C. jessonensis Koidz, Korean hackberry/ezo-enoki (Quednau, 1979); $C$. laevigata (Florida observations); C. nervosa Hemsl., little leaf hackberry (Chinese common name) (Zhang and Zhong 1983); C. sinensis Pers., Japanese hackberry (Higuchi 1972; Zhang and Zhong 1983); C. tetrandra Roxb., Malayan hackberry, (Chakrabarti 1988); and C. tetraneura [sic] (Raychaudhuri et al. 1980). Other hackberry species listed only by Chinese common name include: green hackberry, sand or desert hackberry, Yunnan hackberry, American hackberry and Australian hackberry (Zhang and Zhong 1983).

\section{Survey and Detection}

Look for small (up to $2 \mathrm{~mm}$ ) balls of fuzzy wax on the backs of hackberry leaves. Infestations can be found in both urban and natural landscape situations.

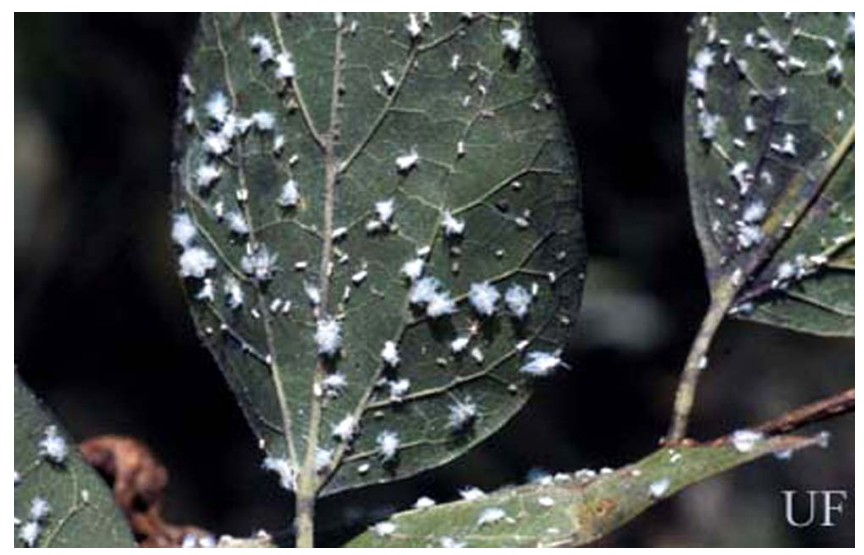

Figure 3. A colony of Shivaphis celti Das, an Asian hackberry aphid, colony on Celtis. Note copious quantities of bluish white wax around the insects. Credits: L.J. Buss, University of Florida

\section{Management}

Chemical: No long-term damage associated with woolly hackberry aphids has been observed; however, aphids may become quite numerous on some trees in late summer. Chemical treatment probably is not warranted for protecting the health of the infested trees.

Biological: Two aphid parasitoids were described from S. celti, including Trioxys (Trioxys) soporensis Shujauddin (Shujauddin 1982) and Trioxys (Binodoxys) jaii Bhagat (Bhagat 1982). Another parasitoid, Trioxys (Trioxys) shivaphis Takada, is mentioned in Shujauddin (1982). The 
efficacy of these parasitoids in controlling the population is not known. No parasitized $S$. celti have been found in Florida so far.

\section{Selected References}

Bhagat RC. 1982. On two new aphid parasitoids of genus Trioxys (Aphidiidae: Hymenoptera) from Kashmir, India. Entomon 7: 321-324.

Blackman RL, Eastop VF.. 1994. Aphids on the world's trees. CAB International, Wallingford, UK. $466 \mathrm{p}$.

Chadrabarti S. 1988. Revision of the Drepanosiphinae (Homoptera: Aphididae) from the Indian subregion. Oriental Insects 22: 1-86.

Higuchi H. 1972. A taxonomic study of the subfamily Callipterinae in Japan. Insecta Matsumurana 35:19-126.

Quednau FW. 1979. Alist of the Drepanosiphine aphids from the Democratic People's Republic of Korea with taxonomic notes and descriptions of new species (Homoptera). Annales Zoologici Polska Akademia Nauk Instytut Zoologii 34: 501-528.

Quednau FW, Remaudière G. 1985. Une nouvelle espèce du genre Shivaphis Das de Turquie (Homoptera: Aphididae). Canadian Entomologist 117: 227-232.

Raychaudhuri DN, Ghosh AK, Basu RC, Ghosh MR, Chattierjee M, Chakrabarti S, Pal PK. 1980. Aphids of north-east India and Bhutan. The Zoological Society, Calcutta. 521 p.

Raychaudhuri D, Raychaudhuri DN, Singh TK. 1981. Redescription of Shivaphis celti (oviparae) and Myzus varians (Homoptera: Aphididae) hitherto unknown from India. Science and Culture 47: 171172.

Remaudière G, Remaudière M. 1997. Catalogue des Aphididae du monde. Institut National de la Recherche Agronomique, Paris. 473 p.

Shujauddin. 1982. Description of a new species of the genus Trioxys Haliday (Hymenoptera: Aphidiidae) and new record of Trioxys (Trioxys) pallidus (Hal.) from Kashmir (India). Journal of Entomological Research 6: 146-149.

Zhang G-x, Zhong T-s. 1990. New species and a new record of Callaphididae and Aphididae from northeast China (Homoptera: Aphididae). Acta Entomologica Sinica 33: 84-88.

1983. Economic Insect Fauna of China, Homoptera: Aphidinea. Science Press, Beijing. Volume 25, Part I. 387 p.

1982. New genera and new species of Chinese Callaphididae and Chaitophoridae (Homoptera). Acta Zootaxonomica Sinica 7: 67-77. 